\title{
Acholeplasma equifetale and Acholeplasma hippikon, Two New Species from Aborted Horse Fetuses
}

\author{
H. KIRCHHOFF \\ Institut für Mikrobiologie und Tierseuchen, Tierärztliche Hochschule Hannover, 3000 Hannover, Germany
}

Six Acholeplasma strains, C1, C112, C117, C581, C589, and PC536, isolated from the lungs, and in one case also from the liver, of aborted horse fetuses exhibited serological properties distinguishing them from the known Acholeplasma species. From the results obtained in growth inhibition, metabolicinhibition, indirect immunofluorescence, and double-immunodiffusion tests, it can be concluded that these strains belong to two new species, for which the names Acholeplasma equifetale and Acholeplasma hippikon are proposed. A. equifetale contains strains C112, C117, C581, and C589, of which C112 (= ATCC 29724) is the type strain. A. hippikon contains strain C1 and PC536, of which C1 (= ATCC 29725) is the type strain.

Recently a number of publications have reported on the isolation of acholeplasmas from a great variety of vertebrate hosts. In horses, acholeplasmas were found in the respiratory tract by Allam et al. (2) and by Ogata et al. (12), and we isolated acholeplasmas from the lungs and livers of aborted horse fetuses (11). Ten strains were cultivated (11). Of these, four were identified as Acholeplasma laidlawii. The remaining six isolates did not belong to any of the known Acholeplasma species: A. laidlawii, A. granularum, A. axanthum, A. modicum, and $A$. oculi. These unidentified organisms were studied to determine whether they belong to new, heretofore undescribed, species.

\section{MATERIALS AND METHODS}

Acholeplasma strains. All of the Acholeplasma strains used in this study were isolated from the lungs of aborted horse fetuses; one of them was also isolated from liver. The designations and sources of the strains are given in Table 1. The Acholeplasma strains used for comparative serological examinations are listed in Table 2. The six isolates were cloned three times by picking single colonies. The fluid culture was filtered through a $450-\mathrm{nm}$ filter, and dilutions of the filtrate were plated on solid medium to produce well-separated colonies.

Culture medium. The Acholeplasma strains were cultivated in a medium of the following composition: heart infusion broth (Oxoid), $720 \mathrm{ml}$; unheated horse serum, $200 \mathrm{ml} ; 25 \%$ (wt/vol) fresh yeast extract, 10 $\mathrm{ml}$; deoxyribonucleic acid (Sigma Chemical Co.), 0.02 g; $1.25 \%$ (wt/vol) thallium acetate, $10 \mathrm{ml}$; and penicillin, $2 \times 10^{6}$ IU. Agar plates were prepared by adding $10 \mathrm{~g}$ of agar (Oxoid) to the fluid medium.

Morphological studies. Acholeplasma colonies were studied by using a stereo microscope (Leitz). Organisms from fluid cultures were studied by darkfield and phase-contrast microscopy (Leitz).

Filtration characteriatics. Filterability of the
Acholeplasma strains was determined by using Swinnex-25 adapters and membrane filters (Millipore Corp.) with a pore diameter of 450 or $200 \mathrm{~nm}$.

Reversion experiments. The isolated strains were passaged seven consecutive times on a substrate without penicillin and thallium acetate. Passages one to five, inclusive, were performed on solid media by sliding inverted agar blocks across the agar surfaces. In the sixth passage, the agar blocks were inoculated into noninhibiting fluid medium and, after incubation, the organisms were examined by dark-field microscopy. The seventh passage was made on solid medium.

Differentiation of acholeplasmas from mycoplasmas. The ability of the organisms to grow at $22^{\circ} \mathrm{C}$ and in medium without serum was tested. The test for cholesterol requirement was carried out as described by Edward (7). The following substrates were used: (i) serum-free medium (meat extract, $10 \mathrm{~g}$; peptone [Oxoid], $10 \mathrm{~g} ; \mathrm{NaCl}, 5 \mathrm{~g}$; agar [Oxoid], $10 \mathrm{~g}$; distilled water, 1 liter); (ii) as (i) but with $19 \mu \mathrm{g}$ of palmitic acid per $\mathrm{ml}$ and $0.5 \%$ bovine serum albumin added; (iii) as (ii) but with $5 \mu \mathrm{g}$ of cholesterol per $\mathrm{ml}$ added. Inhibition of growth by sodium polyanetholsulfonate (Liquoid, Roche Diagnostics) and by digitonin was tested by the disk method (9).

Biochemical tests. Breakdown of the following carbohydrates $(1 \%)$ was determined by the method of Aluotto et al. (3): glucose, lactose, maltose, saccharose, galactose, fructose, arabinose, sorbitol, rhamnose, xylose, mannose, trehalose, dulcitol, inositol, and salicin. The acholeplasmas were also examined for their ability to hydrolyze arginine $(1 \%)$ and urea $(1 \%)$, to reduce 2,3,5-triphenyltetrazolium chloride $(0.2 \%)$ and potassium tellurite $(0.00125,0.0025$, and $0.005 \%)$, to hydrolyze gelatin, to digest casein and coagulated serum, and to produce phosphatase (3). The production of "film and spots" (8) was determined on an agar medium supplemented with $10 \%$ egg yolk emulsion $(\mathrm{Ox}$ oid) and $20 \%$ horse serum and on a medium containing $10 \%$ egg yolk emulsion and $20 \%$ swine serum.

Production of carotenoids. The ability to synthesize carotenoid pigments was investigated in a medium containing sodium acetate according to the procedure 
TABLE 1. Designations and sources of the strains studied

\begin{tabular}{|c|c|}
\hline $\begin{array}{l}\text { Strain designa- } \\
\text { tion }\end{array}$ & Source \\
\hline $\mathrm{Cl}$. & Lung of aborted horse fetus \\
\hline $\mathrm{C} 112$ & Lung of aborted horse fetus \\
\hline $\mathrm{C} 117$ & Lung of aborted horse fetus \\
\hline C581 & Lung and liver of aborted horse fetus \\
\hline C589 . & Lung of aborted horse fetus \\
\hline PC536 & Lung of aborted horse fetus \\
\hline
\end{tabular}

TABLE 2. Sources of the Acholeplasma strains used for serological comparison

\begin{tabular}{|c|c|}
\hline Acholeplasma strain & Source $^{a}$ \\
\hline A. laidlawii A PG8 & $\begin{array}{l}\text { NIH, catalog no. } M- \\
728-001-584\end{array}$ \\
\hline A. granularum BTS-39 & $\begin{array}{l}\text { FAO/WHO Interna- } \\
\text { tional Reference } \\
\text { Center for Animal } \\
\text { Mycoplasmas, Aar- } \\
\text { hus, Denmark }\end{array}$ \\
\hline A. oculi 19L & $\begin{array}{l}\text { FAO/WHO Interna- } \\
\text { tional Reference } \\
\text { Center for Animal } \\
\text { Mycoplasmas, Aar- } \\
\text { hus, Denmark }\end{array}$ \\
\hline A. modicum PG49 & $\begin{array}{l}\text { FAO/WHO Interna- } \\
\text { tional Reference } \\
\text { Center for Animal } \\
\text { Mycoplasmas, Aar- } \\
\text { hus, Denmark }\end{array}$ \\
\hline A. axanthum S-743 & $\begin{array}{c}\text { NCTC, catalog no. } \\
10138\end{array}$ \\
\hline
\end{tabular}

${ }^{a}$ Abbreviations: FAO/WHO, Food and Agricultural Organization, World Health Organization; NIH, National Institutes of Health, Bethesda, Md.; NCTC, National Collection of Type Cultures, London, England.

of Razin and Cleverdon (14), as subsequently modified by Tully and Razin (18).

Hemolysis and hemadsorption. Hemolysis was tested by the overlay technique (3). Hemadsorption was determined as described by Sobeslavsky et al. (16). Both tests were performed with equine, bovine, ovine, canine, rabbit, guinea pig, and chicken erythrocytes.

Electrophoresis of cell proteins. Electrophoretic patterns of the cell proteins of strains $\mathrm{C} 112$ and $\mathrm{C} 1$, as well as of the Acholeplasma strains listed in Table 2, were obtained using the techniques described by Razin and Rottem (15) and as modified for horizontal flat-gel polyacrylamide electrophoresis by Boden and Kirchhoff (4).

Preparation of antisera. For the preparation of antisera, organisms were cultivated in the following medium: phosphate-buffered saline, $765 \mathrm{ml}$; heated swine serum, $200 \mathrm{ml} ; 25 \%$ (wt/vol) fresh yeast extract, $10 \mathrm{ml}$; glucose, $2.5 \mathrm{~g}$; hydrolyzed lactalbumin, $5 \mathrm{~g}$; $1.25 \%$ (wt/vol) thallium acetate, $10 \mathrm{ml}$; and penicillin, $2 \times 10^{6} \mathrm{IU}$. The acholeplasmas were passaged six to eight times in this medium to eliminate traces of horse serum. They were then washed two times in buffered saline, resuspended in 0.01 of the initial volume, emulsified in the same volume of complete Freund adjuvant (Difco), and administered to rabbits by the method of Morton and Roberts (10). The sera produced by this method were used for the serological tests.

Serological tests. The acholeplasmas were compared by using the disk growth inhibition test (GIT) of Clyde (5), the metabolic-inhibition test (MIT) as described by Taylor-Robinson et al. (17), the indirect immunofluorescence test (IFT) of colonies (6), and the double-immunodiffusion technique (13). For the GIT, agar plates without yeast extract and with serum fraction (1\%) were used. Each antigen was diluted $1: 100,1: 500$, and 1:1,000 and was then tested against undiluted antiserum. The plates were incubated at $37^{\circ} \mathrm{C}$ and read shortly after development of colonies. The MIT was performed in microtiter plates. Besides undiluted antigen, dilutions of $1: 10,1: 100,1: 1,000$, and 1:10,000 were tested against the serum dilutions in a medium containing glucose or maltose (1\%), horse serum (20\%), and yeast extract (1\%) in Difco PPLO broth. The microtiter plates were incubated at $37^{\circ} \mathrm{C}$. In the GIT and MIT, tests with the optimal antigen concentration were selected. In the IFT, only young colonies ( 1 and 2 days old) were used because autofluorescence was encountered with older colonies. For gel diffusion, organisms were washed twice in saline $(0.25 \mathrm{M})$, suspended in $1 \%$ sodium deoxycholate in phosphate-buffered saline (pH 8.5), representing a 100 -fold concentration, and kept overnight at room temperature. The extract was centrifuged $(20,000 \times g$ for $30 \mathrm{~min}$ ), and the supernatant, after dialysis against distilled water, was used as antigen.

\section{RESULTS}

Morphological and cultural characteristics. Colonies of all isolates studied exhibited the typical "fried-egg" morphology, with a marked central spot, on solid media. Growth in fluid media reached a maximum between 2 and 3 days of incubation at $37^{\circ} \mathrm{C}$. All isolates grew both aerobically and under $5 \% \mathrm{CO}_{2}$. Phase-contrast and dark-field microscopy of the fluid cultures showed pleomorphic organisms, with coccoid elements dominating. The colonial and cellular morphologies of the isolates were indistinguishable from those of established species of the genus Acholeplasma.

Filterability and reversion. All of the strains passed 450 - and $200-\mathrm{nm}$ filters with a decrease of about $10^{2}$ colony-forming units per $\mathrm{ml}$. There was no reversion to cell wall forms during seven passages on a medium without penicillin and thallium acetate.

Differentiation of acholeplasmas from mycoplasmas. All of the isolates multiplied at $22^{\circ} \mathrm{C}$. Growth occurred on substrate containing cholesterol (iii) as well as on substrate with palmitic acid and bovine serum albumin (ii) 
added and on substrate without supplements (i). All of the isolates were resistant to $20 \%$ sodium polyanetholsulfonate and $1.5 \%$ digitonin.

Biochemical characteristics. The results of the biochemical investigations of the isolates are given in Table 3 . All of the strains showed the same biochemical features. They were found to ferment various carbohydrates aerobically as well as anaerobically. All of the investigated carbohydrates were utilized; however, acid production varied, depending on the carbohydrates used, and was not always reproducible. Strong acid production ( $\mathrm{pH} 5$ and lower) occurred in media containing saccharose, glucose, fructose, maltose, or galactose. The degree of acid production with a given carbohydrate appeared to correlate closely with the number of colonyforming units that developed. All strains were found to be unable to hydrolyze arginine and urea. Reduction of 2,3,5-triphenyltetrazolium chloride was observed in fluid medium only, and even then it was not always reproducible; reduction did not occur on solid medium. Potassium tellurite was reduced by all strains, and the reduction was influenced by various factors, especially the size of the colonies, the duration of incubation, and the concentration of the potassium tellurite. Potassium tellurite reactions were negative on plates with dense growth; large, single colonies usually developed a black coloration, indicative of a positive reaction. The intensity of the coloration increased with the length of incubation. Generally, the most intense coloration was attained after 7 days of incubation. All of the isolates were inhibited by a $0.005 \%$ concentration of potassium tellurite; therefore, lower concentrations $(0.0025$ and $0.00125 \%$ ) were used. The intensity of the col- oration was not influenced by a diminution of the concentration of the potassium tellurite.

Digestion of coagulated serum, hydrolysis of gelatin, digestion of casein, and phosphatase activity were not observed. Production of "film and spots" was found on a medium with $10 \%$ egg yolk emulsion and $20 \%$ horse serum after incubation for 7 days but not on a medium with $10 \%$ egg yolk emulsion and $20 \%$ swine serum.

Production of carotenoids was not observed.

Hemolysis occurred with equine, bovine, ovine, canine, rabbit, guinea pig, and chicken erythrocytes. Hemadsorption did not occur with these erythrocytes.

Electrophoresis of cell proteins. The electrophoretic pattern of the cell proteins of $\mathrm{C} 1$ differed from that of strain $\mathrm{C} 112$, and both patterns differed from those of type strains of established Acholeplasma species (listed in Table 2) (Fig. 1).

Serology. In serological investigations, the six Acholeplasma strains were tested with antisera against strains $\mathrm{C} 1, \mathrm{C} 112$, and $\mathrm{C} 589$ by IFT, GIT, and MIT (Table 4). The investigations indicated that the Acholeplasma isolates belong to two serologically different groups. Strains C1 and PC536 belong to one group, and strains $\mathrm{C} 112, \mathrm{C117}, \mathrm{C} 581$, and $\mathrm{C} 589$ belong to another group.

For comparison with the type strains of the established Acholeplasma species listed in Table 2, strains C1 and C112 were used in the IFT, GIT, MIT, and double-immunodiffusion test. In the IFT, some cross-reactions were observed (Table 5). Compared with the titers obtained for the homologous antisera, these were on a very low level.

Cross-reactions between the type strains of

TABLE 3. Characteristics of six Acholeplasma strains isolated from horses

\begin{tabular}{|c|c|c|c|c|c|c|}
\hline \multirow{2}{*}{ Characteristic } & \multicolumn{6}{|c|}{ Reactions ${ }^{\alpha}$ of Acholeplasma strain: } \\
\hline & $\mathrm{Cl}$ & $\mathrm{C} 112$ & $\mathrm{C} 117$ & C581 & $\mathrm{C} 589$ & PC536 \\
\hline Fermentation of carbohydrates & + & + & + & + & + & + \\
\hline Hydrolysis of arginine & - & - & - & - & - & - \\
\hline Hydrolysis of urea $\ldots \ldots \ldots \ldots$ & - & - & - & - & - & - \\
\hline Reduction of tetrazolium chloride & $(+)$ & $(+)$ & $(+)$ & $(+)$ & $(+)$ & $(+)$ \\
\hline Reduction of potassium tellurite & + & + & + & + & + & + \\
\hline Digestion of coagulated serum & - & - & - & - & - & - \\
\hline Hydrolysis of gelatin $\ldots \ldots$ & - & - & - & - & - & - \\
\hline Digestion of casein & - & - & - & - & - & - \\
\hline Production of phosphatase & - & - & - & - & - & - \\
\hline Production of "film and spots" & + & + & + & + & + & + \\
\hline Production of carotenoids & - & - & - & - & - & - \\
\hline $\begin{array}{l}\text { Hemolysis of equine, bovine, ovine, canine, rabbit, } \\
\text { guinea pig, and chicken erythrocytes } \ldots \ldots\end{array}$ & + & + & + & + & + & + \\
\hline guines pig, and chicken erythrocytes $\ldots \ldots \ldots \ldots$ & - & - & - & - & - & - \\
\hline
\end{tabular}

\footnotetext{
${ }^{a}+$, Positive reaction; - , negative reaction; $(+)$, variable reaction.
} 

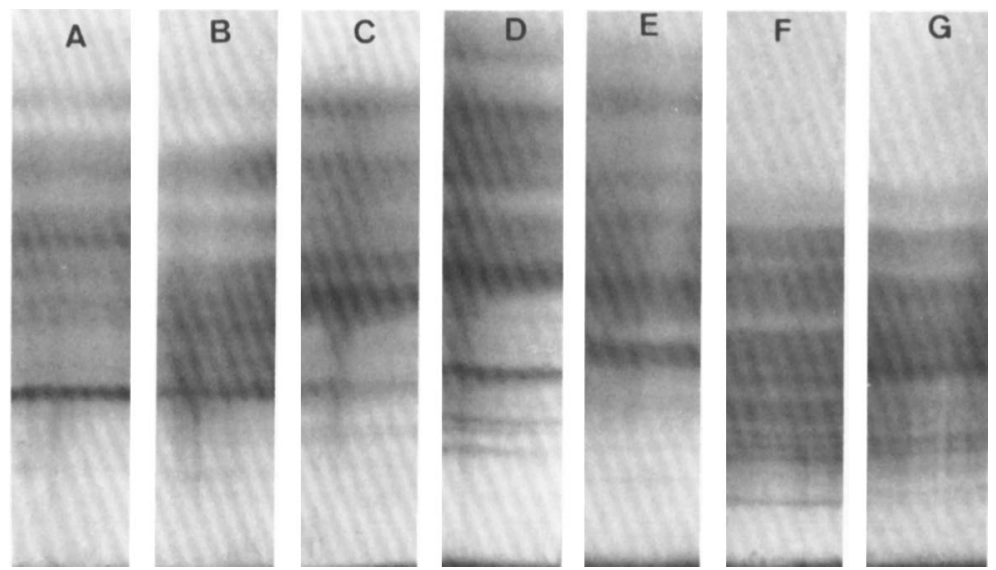

FIG. 1. Electrophoretic patterns of the cell proteins of the type strains of established Acholeplasma species and of strains $C 1$ and C112. (A) A. laidlawii PG8, (B) A. granularum BTS39, (C) A. modicum PG49, (D) A. axanthum $S-743$, (E) A. oculi 19L, (F) strain C112, and (G) strain C1.

TABLE 4. Serological comparison of the isolated Acholeplasma strains with antisera against C1, C112, and C589 in IFT, GIT, and MIT

\begin{tabular}{|c|c|c|c|c|c|c|c|c|c|c|}
\hline \multirow{2}{*}{\multicolumn{2}{|c|}{ Strain }} & \multicolumn{3}{|c|}{ Antiserum against $\mathrm{C} 1$} & \multicolumn{3}{|c|}{ Antiserum against C11? } & \multicolumn{3}{|c|}{ Antiserum against C589 } \\
\hline & & IFT $^{\alpha}$ & GIT $^{b}$ & $\mathrm{MIT}^{c}$ & $\mathrm{IFT}^{a}$ & GIT $^{b}$ & MIT $^{c}$ & IFT $^{a}$ & $\mathrm{GIT}^{b}$ & MIT $^{c}$ \\
\hline $\mathrm{C} 1$. & & + & $5-7$ & $>1,024$ & - & $1-2$ & - & - & - & - \\
\hline $\mathrm{C} 112$ & & - & - & - & + & $6-8$ & $>1,024$ & + & $5-6$ & 256 \\
\hline $\mathrm{C} 117$ & & - & - & - & + & $4-5$ & 512 & ه & $4-5$ & 256 \\
\hline C581 & & - & - & - & + & 5 & 512 & + & 4-5 & 512 \\
\hline C589. & & - & - & - & + & $4-6$ & $>1,024$ & + & $4-6$ & $>1,024$ \\
\hline PC536 & $\ldots \ldots \ldots$ & + & $3-5$ & $>1,024$ & - & - & - & - & - & - \\
\hline
\end{tabular}

${ }^{a}+$, Positive reaction; - , negative reaction.

${ }^{b}$ Inhibition zone in millimeters.

c Reciprocals of serum titer.

Acholeplasma species listed in Table 2 were also observed in the GIT (Table 6). The crossreactions appeared as zones of inhibition 1.5 to $3.0 \mathrm{~mm}$ in diameter. Zones of inhibition in homologous reactions ranged between 4 and $8 \mathrm{~mm}$. Strain C112 showed a weak cross-reaction (2 $\mathrm{mm}$ ) with antiserum against $A$. granularum BTS-39. Strain C112 was slightly inhibited (1to 2 -mm zone of inhibition) by antisera against A. laidlawii PG8, $A$. granularum BTS-39, and strain $\mathrm{C} 1$. Cross-reactions relating to strains $\mathrm{C} 112$ and $\mathrm{Cl}$ were generally weaker than those that occurred between the type strains of the Acholeplasma species listed in Table 2.

The greatest serological specificity, and therefore the greatest difference between the established acholeplasmas and the horse strains, was observed with the MIT (Table 7). Cross-reactions with antisera against the strains of the other Acholeplasma species were observed with A. modicum PG49. Strains C112 and C1 did not cross-react with other acholeplasmas.

The results of the gel diffusion tests are shown in Table 8. The reactions of the antigens with the homologous and heterologous antisera gave six to eight and one to three precipitation lines, respectively.

\section{DISCUSSION}

The morphology of the colonies, the pleomorphic cell form in fluid culture, the passage through 450 and $200-\mathrm{nm}$ filters, and the stability on noninhibiting substrates indicate that the isolates studied belong to the order Mycoplas. matales.

Growth on serum-free and cholesterol-free medium, growth at $22^{\circ} \mathrm{C}$, and resistance to sodium polyanethol sulfonate and digitonin indicate that the isolates belong to the family Acholeplasmataceae. In biochemical investigations, all of the isolates showed the same features. The serological differences observed between isolates $\mathrm{Cl}$ and PC536, on the one hand, and isolates C112, C117, C581, and C589, on the other, indicate that the isolates belong to two different taxa. Representative strains of each 
TABLE 5. Serological relationships of Acholeplasma strains determined by indirect immunofluorescence tests

\begin{tabular}{|c|c|c|c|c|c|c|c|}
\hline \multirow[b]{2}{*}{ Antigen } & \multicolumn{6}{|c|}{ Antiserum against: } & \multirow{2}{*}{-} \\
\hline & $\begin{array}{l}\text { A. laidlawii } \\
\text { PG8 }\end{array}$ & $\begin{array}{c}\text { A. granu- } \\
\text { larum BTS- } \\
39\end{array}$ & $\begin{array}{l}\text { A. axan- } \\
\text { thum S-743 }\end{array}$ & $\begin{array}{l}\text { A. modicum } \\
\text { PG49 }\end{array}$ & $\begin{array}{c}\text { A. oculi } \\
\text { 19L }\end{array}$ & $\mathrm{C} 112$ & \\
\hline A. laidlawii PG8 $\ldots$ & $2,000^{a}$ & & & & & & \\
\hline A. granularum BTS-39 & & 3,500 & & & & & \\
\hline A. axanthum S.743 & & & 6,000 & & & & 200 \\
\hline A, modicum PG49 & & 100 & 500 & 8,000 & & & \\
\hline A. oculi $19 \mathrm{~L} \ldots \ldots \ldots$ & 100 & & & & 8,000 & & \\
\hline $\mathrm{C} 112 \ldots$ & & & & & & 2,500 & \\
\hline $\mathrm{C} 1 \ldots \ldots \ldots \ldots$ & & & & & & & 6,000 \\
\hline
\end{tabular}

${ }^{a}$ Figures are reciprocals of serum titers.

TABLE 6. Serological relationships of Acholeplasma strains determined by growth inhibition tests

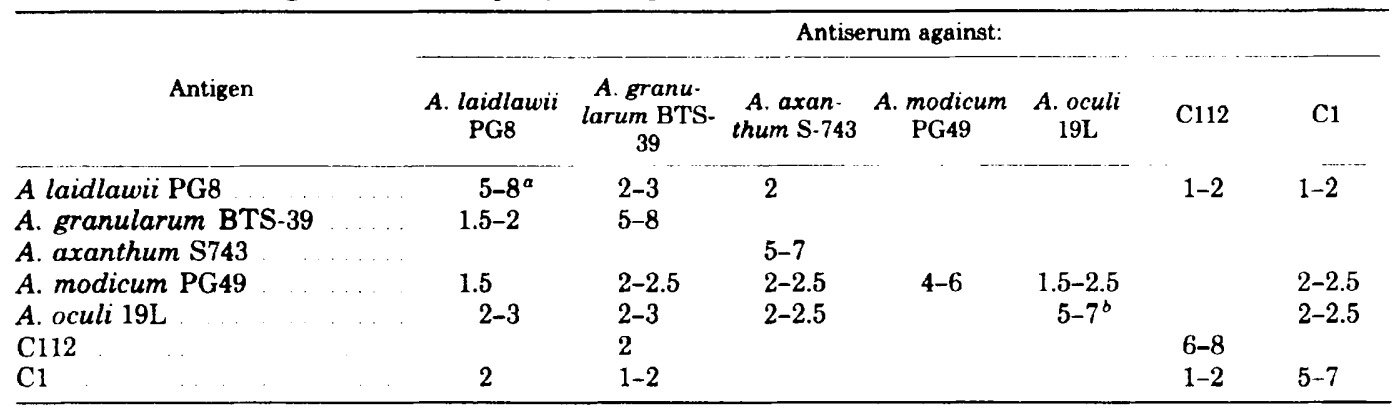

${ }^{a}$ Figures are zones of inhibition in millimeters

${ }^{b}$ Occasionally, some colonies grew within the zone of inhibition.

TABLE 7. Serological relationships of Acholeplasma strains determined by the metabolic-inhibition test

Antiserum against:

Antigen

A. laidlawii PG8

A. granularum BTS-39

A. axanthum $\mathrm{S}-743$

A. modicum PG49

A. oculi $19 \mathrm{~L}$

C112

$\mathrm{C} 1$

${ }^{a}$ Figures are reciprocals of serum titers.

TABLE 8. Serological relationships of Acholeplasma strains determined by the double-immunodiffusion technique

\begin{tabular}{|c|c|c|c|c|c|c|c|}
\hline \multirow[b]{2}{*}{ Antigen } & \multicolumn{7}{|c|}{ Antiserum against: } \\
\hline & $\begin{array}{l}\text { A. laidlawii } \\
\text { PG8 }\end{array}$ & $\begin{array}{c}\text { A. granu- } \\
\text { larum BTS- } \\
39\end{array}$ & $\begin{array}{c}\text { A. axan- } \\
\text { thum } \mathrm{S}-743\end{array}$ & $\begin{array}{l}\text { A. modicum } \\
\text { PG49 }\end{array}$ & $\begin{array}{l}\text { A. oculi } \\
\text { 19L }\end{array}$ & $\mathrm{C} 112$ & $\mathrm{Cl}$ \\
\hline A. laidlawii PG8 .... & $6^{a}$ & 2 & 1 & 2 & 2 & 1 & 1 \\
\hline A. granularum BTS39 & 3 & 8 & 2 & 2 & 2 & 3 & 1 \\
\hline A. axanthum S-743 & 2 & 1 & 6 & 1 & 1 & 2 & 1 \\
\hline A. modicum PG49 & 2 & 2 & 3 & 7 & 2 & 1 & 1 \\
\hline A. oculi 19L & 1 & 3 & 1 & 2 & 7 & 3 & 1 \\
\hline $\mathrm{C} 112$ & 2 & 2 & 1 & 1 & 2 & 6 & 2 \\
\hline $\mathrm{Cl}$ & 2 & 3 & 1 & 2 & 3 & 2 & 7 \\
\hline
\end{tabular}

${ }^{a}$ Figures are numbers of precipitation lines. 
group (C1 and $\mathrm{C} 112)$ differed from the established Acholeplasma species when tested by the IFT, GIT, MIT, and double-immunodiffusion test. Finally, the electrophoretic patterns of the cell proteins of strains $\mathrm{C} 1$ and $\mathrm{C} 112$ differed from each other and from those of the type strains of Acholeplasma species listed in Table 2.

From these results, it can be concluded that the six isolates belong to two new species of the genus Acholeplasma. For the species containing strains C112, C117, C581, and C589, the name Acholeplasma equifetale (L. noun equus horse; L. adj. fetalis fetal; M.L. adj. equifetale pertaining to the horse fetus) is proposed. For the other species, which contains strains $\mathrm{C} 1$ and PC536, the name Acholeplasma hippikon (Gr. adj. hippikon pertaining to the horse) is proposed. The type strain of $A$. equifetale is $\mathrm{C} 112$ and the type strain of $A$. hippikon is $\mathrm{C} 1$. These strains have been deposited in the American Type Culture Collection (ATCC), Rockville, Md., under the numbers 29724 and 29725, respectively, and in the National Collection of Type Cultures (NCTC), London, England.

Recently, it was brought to my attention that an acholeplasma which may belong to $A$. equifetale was found by Allam and Lemke (1) in the respiratory tract of an apparently healthy horse.

\section{ACKNOWLEDGMENTS}

I am greatly indebted to E. A. Freundt for providing cultures of Acholeplasma strains and antisera for comparison, and for much valuable advice. I thank $R$. Lemcke for her help in confirming my results and $J$. Tully for testing for the production of carotenoids.

\section{REPRINT REQUESTS}

Address reprint requests to: Dr. H. Kirchhoff, Institut für Mikrobiologie der Tierärztlichen Hochschule Hannover, Bischofsholer Damm 15, 3000 Hannover, Germany.

\section{LTTERATURE CITED}

1. Allam, N. M., and R. M. Lemcke. 1975. Mycoplasmas isolated from the respiratory tract of horses. J. Hyg. Camb. 74:385-407.

2. Allam, N. M., D. G. Powell, B. E. Andrews, and R. M. Lemcke. 1973. The isolation of Mycoplasma species from horses. Vet. Rec. 93:402

3. Aluotto, B. B., R. G. Wittler, C. O. Williams, and J. E. Faber. 1970. Standardized bacteriologic techniques for the characterization of Mycoplasma species. Int. J. Syst. Bacteriol. 20:35-58.

4. Boden, K., and $H$. Kirchhoff. 1976. Characterization of Acholeplasma strains by horizontal polyacrylamide flat gel electrophoresis. Zentralbl. Bakteriol. Parasitenkd. Infektionskr. Hyg. Abt. 1 Orig. Reihe A 421:342-350.

5. Clyde, W. A. 1964. Mycoplasma species identification based upon growth inhibition by specific antisera. J. Immunol. 92:958-965.

6. Del Guidice, R. A., F. Robillard, and T. R. Carski. 1967. Immunofluorescence identification of $\mathrm{Myco}$ plasma on agar by use of incident illumination. $\mathrm{J}$. Bacteriol. 93:1205-1209.

7. Edward, D. G. 1971. Determination of sterol requirement for Mycoplasmatales. J. Gen. Microbiol. 69:205-210.

8. Fabricant, J., and E. A. Freundt. 1967. Importance of extension and standardization of laboratory tests for the identification and classification of mycoplasma. Ann. N.Y. Acad. Sci. 143:50-58.

9. Freundt, E. A., B. E. Andrews, H. Ernø, M. Kunze, and F. T. Black. 1973. The sensitivity of Mycoplasmatales to sodium polyanetholsulfonate and digitonin. Zentralbl. Bakteriol. Parasitenkd. Infektionskr. Hyg. Abt. 1 Orig. Reihe A 225:104-112.

10. Morton, H. E., and R. J. Roberts. 1966. Production of antimycoplasma (PPLO) antibodies in rabbits. Proc. Soc. Exp. Biol. Med. 125:538-542.

11. Kirchhoff, H., W. Bisping, and W. Floer. 1973. Nachweis von Acholeplasmen und Mykoplasmen in abortierten Pferdefeten. Berl. Muench. Tieraerztl. Wochenschr. 86:401-403.

12. Ogata, M., J. Watabe, and K. Koshimizu. 1974. Classification of acholeplasmas isolated from horses. Jpn. J. Vet. Sci. 38:43.

13. Ouchterlongy,, . 1949. Antigen antibody reactions in gels. Acta Pathol. Microbiol. Scand. 26:507.

14. Ravin, S., and R. C. Cleverdon. 1965. Carotenoids and cholesterol in membranes of Mycoplasma laidlawii. J. Gen. Microbiol. 41:409-415.

15. Raxin, S., and S. Rottem. 1967. Identification of Mycoplasma and other microorganisms by polyacrylamide gel electrophoresis of cell proteins. J. Bacteriol. 94:1807-1810.

16. Sobeslavsky, O., B. Prescott, and R. M. Chanock. 1968. Adsorption of Mycoplasma pneumoniae to neuramic acid receptors of various cells and possible role in virulence. J. Bacteriol. 96:695-705.

17. Taylor-Robinson, D., R. H. Purcell, D. C. Wong, and R. M. Chanock. 1966. A colour test for the measurement of antibody to certain Mycoplasma species based upon the inhibition of acid production. J. Hyg. 64: $91-104$.

18. Tully, J. G., and S. Raxin. 1968. Physiological and serological comparisons among strains of Mycoplasma granularum and Mycoplasma laidlawii. J. Bacteriol. 95:1504-1512. 